\title{
Analysis of the Associations between Vitamin D and Albuminuria or $\beta$-Cell Function in Chinese Type 2 Diabetes
}

\author{
Xiaoling Cai, Zhaoheng Hu, Ling Chen, Xueyao Han, and Linong Ji \\ Endocrine \& Metabolism Department, Peking University People’s Hospital, Beijing 100044, China \\ Correspondence should be addressed to Linong Ji; prof_jilinong@aliyun.com
}

Received 12 December 2013; Revised 18 March 2014; Accepted 31 March 2014; Published 23 April 2014

Academic Editor: Ali Rizvi

Copyright (C) 2014 Xiaoling Cai et al. This is an open access article distributed under the Creative Commons Attribution License, which permits unrestricted use, distribution, and reproduction in any medium, provided the original work is properly cited.

Objective. To investigate the associations of $25-(\mathrm{OH}) \mathrm{D}$ and $\beta$-cell function or insulin resistance or albuminuria in Chinese type 2 diabetic patients. Methods. In total, 1408 type 2 diabetic patients without vitamin D supplement were included in this retrospective study. Results. Comparison between patients with and without $25-(\mathrm{OH}) \mathrm{D}$ deficiency indicated that, compared with patients with $25-(\mathrm{OH}) \mathrm{D} \geq 50 \mathrm{nmol} / \mathrm{L}$, patients with $25-(\mathrm{OH}) \mathrm{D}<50 \mathrm{nmol} / \mathrm{L}$ showed a higher level of urine albumin-creatinine ratio (ACR) $(90.15 \pm 10.30 \mathrm{mg} / \mathrm{g}$ versus $52.79 \pm 14.97 \mathrm{mg} / \mathrm{g})$. Multiple regression analysis indicated that $25-(\mathrm{OH}) \mathrm{D}$ was independently and negatively correlated with urine ACR (OR $=0.985,95 \% \mathrm{CI} 0.972-0.999, P=0.03$ ), adjusted by age, diabetic duration, HBP duration, SBP, HbAlc, creatinine, LDL-C, triglyceride, total cholesterol, and HDL-C. Compared with patients with normal level of urine ACR, patients with higher level of urine ACR showed a significant lower level of $25-(\mathrm{OH}) \mathrm{D}(34.49 \pm 13.52 \mathrm{nmol} / \mathrm{L}$ versus $37.46 \pm 13.6 \mathrm{nmol} / \mathrm{L}, P=0.00)$. Analysis of the associations of $25-(\mathrm{OH}) \mathrm{D}$ and $\beta$-cell function or insulin resistance showed that $25-(\mathrm{OH}) \mathrm{D}$ may not correlate with $\beta$-cell function or insulin resistance. Conclusion. $25-(\mathrm{OH}) \mathrm{D}$ was independently associated with albuminuria in Chinese type 2 diabetic patients but was not associated with $\beta$-cell function or insulin resistance.

\section{Introduction}

Recently, accumulating evidence from several cross-sectional studies indicated that a factor that may impact the differential development of diabetic nephropathy is vitamin $\mathrm{D}$. The role of the kidney in the hydroxylation of the vitamin D metabolite 25-OH-D from the liver to the biologically active form of $1,25-(\mathrm{OH}) 2 \mathrm{D} 3$ is well established $[1,2]$. Animal studies suggested that vitamin $\mathrm{D}$ deficiency and insufficiency may have an active role in the progression of kidney disease [3-6]. Another interesting thing is that racial and ethnic differences exist in the prevalence of diabetic nephropathy $[7,8]$. However, little information is available about the association between diabetic nephropathy and vitamin D levels in humans, especially in Chinese population.

Moreover, evidence from several cross-sectional studies also indicated that high serum 25-hydroxyvitamin D [25$(\mathrm{OH}) \mathrm{D}]$ concentration may be associated with lower risk of insulin resistance, high level of insulin secretion, and lower risk of type 2 diabetes [9-14]. However, reports on associations between insulin secretion or insulin resistance and 25- $(\mathrm{OH}) \mathrm{D}$ have been inconsistent. What's more, how about the relation between insulin secretion or insulin resistance and 25(OH)D level in established diabetes patients? Few studies have examined these relationships in Asians especially in the Chinese.

Therefore, in the current study, we make two hypotheses: one is that there might be an association between vitamin $\mathrm{D}$ and albuminuria in Chinese type 2 diabetes patients; the other is that vitamin $\mathrm{D}$ might be inversely associated with insulin resistance and $\beta$-cell dysfunction in established Chinese type 2 diabetes population.

\section{Materials and Methods}

2.1. Patients. By searching inpatient database at Peking University People's Hospital, we have identified 1408 type 2 diabetic patients who were hospitalized for treatment at the ward of Department of Endocrinology and Metabolism of Peking University People's Hospital from January 2009 to December 2012. From that period of time, patients being hospitalized 
into our endocrinology department were all included in this retrospective study. Reasons for hospitalization were as follows: (1) advancement of oral hypoglycemic agents treatment or insulin treatment for better glycemic control, (2) optimizing the antidiabetic treatment and the treatment of diabetes complications, and (3) routine screening for diabetes complications by the patients' will. Patients with diabetic ketoacidosis or ketonuria and who tested positive for antiglutamic acid decarboxylase and islet cell antibody were excluded. Patients with routine vitamin D supplement or other treatment for osteoporosis before admission were excluded. The consent forms were all signed by the patients.

2.2. Ethics Statement. This is a retrospective study and the data were analysed anonymously; therefore, there is no need for informed consent. The ethics committee of Peking University People's Hospital has approved this retrospective study. All the patients were patients admitted at the Department of Endocrine \& Metabolism of Peking University People's Hospital. On the first day of their admission, the patients signed the consent form for allowing their information to be stored in the hospital database and used for research. This consent form was also approved by the ethics committee of Peking University People's Hospital.

2.3. Variable Assessment. Anthropometric measurements at admission were collected; biochemical measurements including HbA1c (Primus ultra2, Primus Diagnostics, MO, USA), urinary albumin-creatinine ratio (COBAS Integra 400 Plus System, Roche Diagnostics Ltd., Basel, Switzerland), immunoreactive fasting insulin (Elecsys 2010 system, Roche Diagnostics Ltd., Basel, Switzerland), levels of total cholesterol (CHO), low-density lipoprotein cholesterol (LDL-C), high-density lipoprotein cholesterol (HDL-C), and triglyceride (COBAS Integra 400 Plus System, Roche Diagnostics Ltd., Basel, Switzerland) were assessed. Serum 25-(OH)D was determined by competitive RIA using the IDS RIA kit (Medicorp Inc.).

The homeostasis model assessment of insulin resistance (HOMA-IR) and HOMA-B were derived from fasting glucose and insulin levels. HOMA-IR was calculated using the formula fasting glucose $(\mathrm{mmol} / \mathrm{L}) \times$ fasting insulin $(\mathrm{pmol} / \mathrm{L}) / 22.5$; HOMA-B was calculated using $20 \times$ fasting insulin $(\mathrm{pmol} / \mathrm{L}) /($ fasting glucose $(\mathrm{mmol} / \mathrm{L})-3.5)$.

\subsection{Definition of Albuminuria and Vitamin D Deficiency.} Urinary albumin-to-creatinine ratio (ACR) was tested in three consecutive days for each patient, and the average ACR was calculated. The urine samples were collected in the early morning each day. Albuminuria was defined as urinary albumin-to-creatinine ratio $\geq 30 \mathrm{mg} / \mathrm{g}$. Serum 25 hydroxycalciferol vitamin $\mathrm{D}$ levels were characterized as $<50 \mathrm{nmol} / \mathrm{L}$ vitamin $\mathrm{D}$ deficiency, 50 to $75 \mathrm{nmol} / \mathrm{L}$ vitamin $\mathrm{D}$ insufficiency, and $>75 \mathrm{nmol} / \mathrm{L}$ normal vitamin $\mathrm{D}$.

2.5. Statistical Analysis. Variables were represented as means \pm s.d. Continuous variables were compared using a two-sample $t$ test while frequency of dichotomous variables was performed by $\chi^{2}$ analysis. A two-sided $P \leq 0.05$ was considered significant. Multivariable logistic regression analyses were made to assess the correlation between serum 25-(OH)D (VitD) and HOMA-IR, HOMA-B, or urine ACR. All $P$ values were 2-tailed and considered significant at $P<0.05$. Regression analyses were performed using SPSS 19.0.

\section{Results}

3.1. Clinical and Metabolic Parameters of Patients. Clinical characteristics of patients were shown in Table 1. The average age was $57.09 \pm 13.54$ years old; the average diabetic duration was $9.39 \pm 7.73$ years. The average HbAlc was $8.95 \pm 2.11 \%$. The level of $25-(\mathrm{OH}) \mathrm{D}$ was $35.72 \pm 13.64 \mathrm{nmol} / \mathrm{L}$. The average HOMA-IR was $5.28 \pm 7.49$ and HOMA-B was $119.37 \pm$ 409.89. The average urine ACR was $84.21 \pm 293.12 \mathrm{mg} / \mathrm{g}$.

3.2. Comparisons between Patients with Different Level of 25$(\mathrm{OH}) \mathrm{D}$. Patients with $25-(\mathrm{OH}) \mathrm{D}$ deficiency occupied $84.4 \%$, while patients with $25-(\mathrm{OH}) \mathrm{D}$ insufficiency occupied $14.16 \%$, only $1.44 \%$ patients with normal level of $25-(\mathrm{OH}) \mathrm{D}$. Comparisons between patients with and without $25-(\mathrm{OH}) \mathrm{D}$ deficiency indicated that, compared with patients with $25-(\mathrm{OH}) \mathrm{D}$ $\geq 50 \mathrm{nmol} / \mathrm{L}$, patients with $25-(\mathrm{OH}) \mathrm{D}<50 \mathrm{nmol} / \mathrm{L}$ showed a higher level of HbAlc $(9.03 \pm 0.07 \%$ versus $8.55 \pm 0.16 \%$, $P=0.01)$, a higher level of TG $(1.96 \pm 0.05 \mathrm{mmol} / \mathrm{L}$ versus $1.65 \pm 0.08 \mathrm{mmol} / \mathrm{L}, P=0.02)$, and a higher level of urine ACR (90.15 $\pm 10.30 \mathrm{mg} / \mathrm{g}$ versus $52.79 \pm 14.97 \mathrm{mg} / \mathrm{g}$ ) (Table 1).

3.3. Association between Serum 25-(OH)D Concentration and Albuminuria. Then, multiple logistic regression analysis was used to identify the association between serum 25-(OH)D concentration and urine ACR. Urine ACR was used as dependent variable, gender, diabetic duration, age, and season of the examination as independent variables in model 1 , model 1 and BMI, SBP, and HbAlc as independent variables in model 2, and model 2 and LDL-C, HDL-C, triglyceride, total cholesterol, CRE, and UA level as independent variables in model 3. Results showed that serum $25-(\mathrm{OH}) \mathrm{D}$ concentration was associated with urine ACR in each model (model 1: OR = 0.984, 95\% CI 0.972-0.996, $P=0.008$; model 2: OR $=0.985$, 95\% CI 0.973-0.998, $P=0.021$; model 3: OR $=0.985,95 \%$ CI $0.972-0.999, P=0.030)$. The lower level of serum $25-(\mathrm{OH}) \mathrm{D}$ was associated with the high level of urine ACR. Details were shown in Table 2. Compared with patients with normal level of urine ACR, patients with higher level of urine ACR showed a significant lower level of $25-(\mathrm{OH}) \mathrm{D}(34.49 \pm 13.52 \mathrm{nmol} / \mathrm{L}$ versus $37.46 \pm 13.6 \mathrm{nmol} / \mathrm{L}, P=0.00)$. Details were shown in Table 2.

\subsection{Association between Serum 25-(OH)D Concentration and} Insulin Resistance. Then, multiple logistic regression analysis was used to identify the association between serum 25$(\mathrm{OH}) \mathrm{D}$ concentration and insulin resistance. HOMA-IR was used as dependent variable, gender, diabetic duration, age, and season of the examination as independent variables in model 1, model 1 and BMI, SBP, and HbAlc as independent 
TABLE 1: Comparisons between patients with different level of 25-(OH)D.

\begin{tabular}{|c|c|c|c|c|}
\hline & All patients & $25-(\mathrm{OH}) \mathrm{D}<50 \mathrm{nmol} / \mathrm{L}$ & $25-(\mathrm{OH}) \mathrm{D} \geq 50 \mathrm{nmol} / \mathrm{L}$ & $P$ value \\
\hline Number of patients & 1408 & 1097 & 311 & \\
\hline Gender (male/female) & $57.4 \% / 42.6 \%$ & $59.6 \% / 40.4 \%$ & $65.9 \% / 34.1 \%$ & 0.09 \\
\hline Age (years) & $57.1 \pm 13.54$ & $57.5 \pm 12.9$ & $57.0 \pm 12.5$ & 0.63 \\
\hline Duration of DM (years) & $9.4 \pm 7.7$ & $9.4 \pm 7.8$ & $10.1 \pm 7.4$ & 0.29 \\
\hline BMI $\left(\mathrm{kg} / \mathrm{m}^{2}\right)$ & $25.24 \pm 4.00$ & $25.38 \pm 3.80$ & $25.27 \pm 3.44$ & 0.72 \\
\hline Waist $(\mathrm{cm})$ & $91.9 \pm 12.1$ & $92.1 \pm 11.6$ & $90.9 \pm 13.6$ & 0.24 \\
\hline $\mathrm{SBP}(\mathrm{mmHg})$ & $131.7 \pm 17.3$ & $131.1 \pm 17.4$ & $132.3 \pm 15.2$ & 0.59 \\
\hline $\mathrm{DBP}(\mathrm{mmHg})$ & $78.8 \pm 11.2$ & $78.7 \pm 11.4$ & $80.2 \pm 10.48$ & 0.13 \\
\hline 25-(OH)D (nmol/L) & $35.72 \pm 13.64$ & $32.41 \pm 8.02$ & $60.22 \pm 11.20$ & 0.00 \\
\hline HbAlc (\%) & $8.95 \pm 2.11$ & $9.03 \pm 2.10$ & $8.55 \pm 2.05$ & 0.01 \\
\hline Fasting glucose $(\mathrm{mmol} / \mathrm{L})$ & $8.07 \pm 2.83$ & $8.17 \pm 2.83$ & $7.70 \pm 2.80$ & 0.01 \\
\hline Fasting insulin (uU/mL) & $14.65 \pm 18.95$ & $14.98 \pm 19.17$ & $12.90 \pm 17.66$ & 0.27 \\
\hline HOMA-B & $119.37 \pm 409.89$ & $124.68 \pm 454.9$ & $91.91 \pm 168.3$ & 0.41 \\
\hline HOMA-IR & $5.28 \pm 7.49$ & $5.41 \pm 7.90$ & $4.63 \pm 5.75$ & 0.30 \\
\hline Postprandial insulin $(\mathrm{uU} / \mathrm{mL})$ & $62.59 \pm 119.61$ & $62.24 \pm 112.7$ & $64.46 \pm 152.1$ & 0.85 \\
\hline $\mathrm{UA}(\mathrm{umol} / \mathrm{L})$ & $313.5 \pm 90.3$ & $312.2 \pm 89.6$ & $329.8 \pm 92.0$ & 0.02 \\
\hline CRE (umol/L) & $63.48 \pm 31.26$ & $62.09 \pm 37.43$ & $61.34 \pm 18.18$ & 0.79 \\
\hline $\mathrm{CHO}(\mathrm{mmol} / \mathrm{L})$ & $4.74 \pm 1.19$ & $4.76 \pm 1.19$ & $4.59 \pm 1.11$ & 0.12 \\
\hline $\mathrm{TG}(\mathrm{mmol} / \mathrm{L})$ & $1.88 \pm 1.58$ & $1.96 \pm 1.70$ & $1.65 \pm 1.01$ & 0.02 \\
\hline $\mathrm{HDL}-\mathrm{C}(\mathrm{mmol} / \mathrm{L})$ & $1.17 \pm 2.82$ & $1.06 \pm 0.41$ & $1.08 \pm 0.32$ & 0.42 \\
\hline LDL-C (mmol/L) & $2.65 \pm 0.84$ & $2.70 \pm 0.82$ & $2.68 \pm 0.88$ & 0.75 \\
\hline hsCRP (mg/L) & $3.0 \pm 3.4$ & $3.1 \pm 3.0$ & $2.5 \pm 3.4$ & 0.09 \\
\hline Urine ALB (mg/g) & $84.2 \pm 293.1$ & $90.1 \pm 305.3$ & $52.8 \pm 243.0$ & 0.04 \\
\hline
\end{tabular}

variables in model 2, and model 2 and LDL-C, HDL-C, triglyceride, total cholesterol, CRE, UA level, and urine ACR as independent variables in model 3 . Results showed that serum 25- $(\mathrm{OH}) \mathrm{D}$ concentration was not associated with HOMA-IR in each model. Details were shown in Table 2.

3.5. Association between Serum 25-(OH)D Concentration and $\beta$-Cell Function. Then, multiple logistic regression analysis was used to identify the association between serum $25-(\mathrm{OH}) \mathrm{D}$ concentration and $\beta$-cell function. HOMA-B was used as dependent variable, gender, diabetic duration, age, and season of the examination as independent variables in model 1, model 1 and BMI, SBP, and HbAlc as independent variables in model 2, and model 2 and LDL-C, HDL-C, triglyceride, total cholesterol, CRE, UA level, and urine ACR as independent variables in model 3 . Results showed that serum 25- $(\mathrm{OH}) \mathrm{D}$ concentration was not associated with HOMA-B in each model. Details were shown in Table 2.

\section{Discussion}

This study suggested independent association of $25-(\mathrm{OH}) \mathrm{D}$ with albuminuria but did not find the associations of insulin sensitivity and $\beta$-cell function with $25-(\mathrm{OH}) \mathrm{D}$ in Chinese type 2 diabetes patients.

The major contribution of this study is the finding of an association between vitamin D and urine ACR, an index of diabetic nephropathy in Chinese type 2 diabetes patients. Multiple logistic regression analysis indicated that serum $25-(\mathrm{OH}) \mathrm{D}$ concentration was inversely correlated with urine ACR. In Caucasian patients, Diaz et al. [15] reported according to a cross-sectional analysis of the 2001 to 2006 National Health and Nutrition Examination Survey that higher proportions of individuals with nephropathy have vitamin $\mathrm{D}$ deficiency than individuals without nephropathy (53.2\% versus $47.0 \%, P<0.03$ ). They also demonstrated that vitamin $\mathrm{D}$ deficiency and insufficiency were associated with the presence of nephropathy (odds ratio, 1.85; 95\% CI, 1.06-3.23 for vitamin D deficiency; and odds ratio, 1.79; 95\% CI, 1.12-2.85 for vitamin D insufficiency), the results of which were in accordance with ours. However, because of the nature of this retrospective study, we were unable to determine whether this association is present because vitamin $\mathrm{D}$ deficiency increases the risk of nephropathy or because nephropathy increases the risk of vitamin D deficiency. This study evaluates 25-OH-D, as the NHANES study, which is the circulating metabolite produced in the liver that is later metabolized in the kidneys to 1,25-(OH)2D3. Based on this well-established pathway, renal insufficiency could not be the reason for the low levels of 25-OH-D seen in the study. This suggests that studies to further describe the role of vitamin $\mathrm{D}$ as a possible risk marker or risk factor for albuminuria and diabetic nephropathy are needed to evaluate the impact of maintaining an adequate level of vitamin $\mathrm{D}$ on the progression of diabetic nephropathy.

In terms of the association of vitamin $\mathrm{D}$ and beta cell function and insulin resistance, there are several potential 
TABLE 2: Associations between serum 25-(OH)D concentration and insulin resistance, $\beta$-cell function, and urine ACR in Chinese type 2 diabetes.

\begin{tabular}{lccc}
\hline & OR & $95 \%$ CI & $P$ value \\
\hline \multicolumn{4}{c}{ 25-(OH)D concentration $(\mathrm{nmol} / \mathrm{L})$ and HOMA-IR } \\
Model 1 & 1.012 & $1.002-1.024$ & 0.025 \\
Model 2 & 1.009 & $0.996-1.021$ & 0.169 \\
Model 3 & 1.009 & $0.997-1.022$ & 0.150 \\
\hline \multicolumn{4}{c}{ 25-(OH)D concentration $(\mathrm{nmol} / \mathrm{L})$ and HOMA-B } \\
Model 1 & 0.999 & $0.988-1.010$ & 0.830 \\
Model 2 & 0.994 & $0.983-1.006$ & 0.336 \\
Model 3 & 0.992 & $0.981-1.004$ & 0.206 \\
\hline \multicolumn{4}{c}{$25-(\mathrm{OH}) \mathrm{D}$ concentration $(\mathrm{nmol} / \mathrm{L})$ and urine ACR $(\mathrm{mg} / \mathrm{g})^{* * *}$} \\
Model 1 & 0.984 & $0.972-0.996$ & 0.008 \\
Model 2 & 0.985 & $0.973-0.998$ & 0.021 \\
Model 3 & 0.985 & $0.972-0.999$ & 0.030 \\
\hline
\end{tabular}

${ }^{*}$ Model 1: adjusted by gender, age (year), duration of diabetes (year), and season; model 2: adjusted by model $1+\mathrm{BMI}\left(\mathrm{kg} / \mathrm{m}^{2}\right)$, SBP $(\mathrm{mmHg})$, and HbAlc (\%); model 3: adjusted by model $2+$ urine ACR (mg/g), LDL-C $(\mathrm{mmol} / \mathrm{L}), \mathrm{HDL}-\mathrm{C}(\mathrm{mmol} / \mathrm{L}), \mathrm{CHO}(\mathrm{mmol} / \mathrm{L}), \mathrm{TG}(\mathrm{mmol} / \mathrm{L}), \mathrm{UA}(\mathrm{umol} / \mathrm{L})$, and CRE (umol/L). HOMA-IR $>3.30$ as 1 , while HOMA-IR $<3.30$ as 2 .

${ }^{* *}$ Model 1: adjusted by gender, age (year), duration of diabetes (year), and season; model 2: adjusted by model $1+\mathrm{BMI}\left(\mathrm{kg} / \mathrm{m}^{2}\right)$, SBP $(\mathrm{mmHg})$, and HbAlc (\%); model 3: adjusted by model $2+$ urine ACR (mg/g), LDL-C (mmol/L), HDL-C (mmol/L), CHO (mmol/L), TG (mmol/L), UA (umol/L), and CRE (umol/L). HOMA-B $<50$ as 1, while HOMA-B $>50$ as 2 .

${ }^{* * *}$ Model 1: adjusted by gender, age (year), duration of diabetes (year), and season; model 2: adjusted by model $1+\mathrm{BMI}\left(\mathrm{kg} / \mathrm{m}^{2}\right)$, SBP $(\mathrm{mmHg})$, and HbAlc (\%); model 3: adjusted by model $2+$ LDL-C (mmol/L), HDL-C $(\mathrm{mmol} / \mathrm{L}), \mathrm{CHO}(\mathrm{mmol} / \mathrm{L}), \mathrm{TG}(\mathrm{mmol} / \mathrm{L}), \mathrm{UA}(\mathrm{umol} / \mathrm{L})$, and CRE (umol/L). Urine ACR $<30 \mathrm{mg} / \mathrm{g}$ as 1 , while urine ACR $\geq 30 \mathrm{mg} / \mathrm{g}$ as 2 .

effects of vitamin $\mathrm{D}$ on pancreatic beta cell function and insulin action [16-21]. The direct effect of vitamin D may be mediated by binding of its circulating active form 1,25$(\mathrm{OH}) 2 \mathrm{D} 3$ to the beta cell vitamin D receptor. The indirect effects of vitamin $\mathrm{D}$ may be mediated via its role in regulating extracellular calcium and calcium flux through the beta cell. Changes in calcium influx in primary insulin target tissues may contribute to peripheral insulin resistance. However, reports on associations between insulin secretion or insulin resistance and vitamin D have been inconsistent [22-30]. According to this study in Chinese type 2 diabetes patients, the level of 25- $(\mathrm{OH}) \mathrm{D}$ may not be associated with HOMA$B$, an index of pancreatic beta cell function derived from fasting insulin and glucose concentrations, and may not be associated with HOMA-IR, an index of insulin resistance. Boucher and others in several cohorts [22-26] reported that hypovitaminosis $\mathrm{D}$ is associated with beta cell dysfunction, but not in Lind et al. [27] and Orwoll et al. [28] studies. Baynes and others reported in several cross-sectional studies that there were associations between low vitamin D level and decreased insulin sensitivity [23-30], but not in Orwoll et al. [28] study. The differences in this relationship are likely due to differences in subject populations and disparate methods to determine insulin secretion.

In general, this retrospective study has shown some limitations. This study investigating relationships between
25- $(\mathrm{OH}) \mathrm{D}$ and insulin secretion and sensitivity used indirect proxy measures, as HOMA-IR and HOMA-B. The accuracy of proxy measures of insulin sensitivity may vary depending on obesity status. In addition, although more than a thousand patients were included in this study, the sample size for evaluating the association between $25-(\mathrm{OH}) \mathrm{D}$ and insulin secretion and sensitivity may be small. However, as far as we know, this study may be the first study in Chinese type 2 diabetes patients to assess the relationship of $25-(\mathrm{OH}) \mathrm{D}$ and insulin secretion and sensitivity as well as the relationship of $25-(\mathrm{OH}) \mathrm{D}$ and urine ACR. Furthermore, the nature of this retrospective study results in the limitation to infer causation.

In conclusion, this study suggested that $25-(\mathrm{OH}) \mathrm{D}$ was significantly correlated with albuminuria in Chinese type 2 diabetic patients but may not be associated with $\beta$-cell function or insulin resistance.

\section{Abbreviations}

$\begin{array}{ll}\text { 25-(OH)D: } & \text { 25-Hydroxyvitamin D } \\ \text { 95\% CI: } & \text { 95\% confidence interval } \\ \text { ACR: } & \text { Albumin-creatinine ratio } \\ \text { BMI: } & \text { Body mass index } \\ \text { CHO: } & \text { Total cholesterol } \\ \text { CRE: } & \text { Creatinine } \\ \text { CRP: } & \text { C reactive protein } \\ \text { DBP: } & \text { Diastolic blood pressure } \\ \text { DM: } & \text { Diabetes mellitus } \\ \text { HbAlc: } & \text { Hemoglobin Alc } \\ \text { HBP: } & \text { Hypertension } \\ \text { HDL-C: } & \text { High-density lipoprotein cholesterol } \\ \text { HOMA-B: } & \text { Homeostasis model assessment of } \beta \text {-cell } \\ & \text { function } \\ \text { HOMA-IR: } & \text { Homeostasis model assessment of insulin } \\ & \text { resistance } \\ \text { LDL-C: } & \text { Low-density lipoprotein cholesterol } \\ \text { OR: } & \text { Odds ratio } \\ \text { SBP: } & \text { Systolic blood pressure } \\ \text { TG: } & \text { Triglyceride } \\ \text { UA: } & \text { Uric acid } \\ \text { WHR: } & \text { Waist hip ratio. } \\ & \end{array}$

\section{Conflict of Interests}

The authors declare that there is no conflict of interests regarding the publication of this paper.

\section{Acknowledgments}

This retrospective study was supported by all the staff working at Peking University People's Hospital's Endocrinology \& Metabolism Department. Special thanks are due to Ling Chen and Hui Wan for collecting patients' data.

\section{References}

[1] M. F. Holick, "Medical progress: vitamin D deficiency," The New England Journal of Medicine, vol. 357, no. 3, pp. 266-281, 2007. 
[2] National Kidney Foundation, "K/DOQI clinical practice guidelines for bone metabolism and disease in chronic kidney disease," American Journal of Kidney Diseases, vol. 42, supplement 3, pp. S1-S201, 2003.

[3] G. Klaus, "Renoprotection with vitamin D: specific for diabetic nephropathy?" Kidney International, vol. 73, no. 2, pp. 141-143, 2008.

[4] Z. Zhang, L. Sun, Y. Wang et al., "Renoprotective role of the vitamin D receptor in diabetic nephropathy," Kidney International, vol. 73, no. 2, pp. 163-171, 2008.

[5] A. Kuhlmann, C. S. Haas, M.-L. Gross et al., "1,25Dihydroxyvitamin D3 decreases podocyte loss and podocyte hypertrophy in the subtotally nephrectomized rat," American Journal of Physiology: Renal Physiology, vol. 286, no. 3, pp. F526-F533, 2004.

[6] U. Schwarz, K. Amann, S. R. Orth, A. Simonaviciene, S. Wessels, and E. Ritz, "Effect of 1,25(OH)2 vitamin D3 on glomerulosclerosis in subtotally nephrectomized rats," Kidney International, vol. 53, no. 6, pp. 1696-1705, 1998.

[7] J. L. Gross, M. J. De Azevedo, S. P. Silveiro, L. H. Canani, M. L. Caramori, and T. Zelmanovitz, "Diabetic nephropathy: diagnosis, prevention, and treatment," Diabetes Care, vol. 28, no. 1, pp. 164-176, 2005.

[8] H. E. Resnick, G. L. Foster, J. Bardsley, and R. E. Ratner, "Achievement of American Diabetes Association clinical practice recommendations among U.S. adults with diabetes, 19992002: the National Health and Nutrition Examination Survey," Diabetes Care, vol. 29, no. 3, pp. 531-537, 2006.

[9] A. G. Pittas, J. Lau, F. B. Hu, and B. Dawson-Hughes, "The role of vitamin $\mathrm{D}$ and calcium in type 2 diabetes. A systematic review and meta-analysis," Journal of Clinical Endocrinology and Metabolism, vol. 92, no. 6, pp. 2017-2029, 2007.

[10] E. S. Ford, U. A. Ajani, L. C. McGuire, and S. Liu, "Concentrations of serum vitamin D and the metabolic syndrome among U.S. adults," Diabetes Care, vol. 28, no. 5, pp. 1228-1230, 2005.

[11] A. G. Pittas, M. Chung, T. Trikalinos et al., "Systematic review: vitamin D and cardiometabolic outcomes," Annals of Internal Medicine, vol. 152, no. 5, pp. 307-314, 2010.

[12] J. Mitri, M. D. Muraru, and A. G. Pittas, "Vitamin D and type 2 diabetes: a systematic review," European Journal of Clinical Nutrition, vol. 65, no. 9, pp. 1005-1015, 2011.

[13] A. C. Ross, C. L. Taylor, A. L. Yaktine, and H. B. Del Valle, Dietary Reference Intakes for Calcium and Vitamin D, National Academies Press, Washington, DC, USA, 2011.

[14] A. Ashraf and J. A. Alvarez, "Role of vitamin D in insulin secretion and insulin sensitivity for glucose homeostasis," International Journal of Endocrinology, vol. 2010, Article ID 351385, 18 pages, 2010.

[15] V. A. Diaz, A. G. Mainous III, P. J. Carek, A. M. Wessell, and C. J. Everett, "The association of vitamin D deficiency and insufficiency with diabetic nephropathy: implications for health disparities," Journal of the American Board of Family Medicine, vol. 22, no. 5, pp. 521-527, 2009.

[16] R. D. G. Milner and C. N. Hales, "The role of calcium and magnesium in insulin secretion from rabbit pancreas studied in vitro," Diabetologia, vol. 3, no. 1, pp. 47-49, 1967.

[17] B. Draznin, K. Sussman, M. Kao, D. Lewis, and N. Sherman, "The existence of an optimal range of cytosolic free calcium for insulin-stimulated glucose transport in rat adipocytes," Journal of Biological Chemistry, vol. 262, no. 30, pp. 14385-14388, 1987.
[18] S. Segal, S. Lloyd, N. Sherman, K. Sussman, and B. Draznin, "Postprandial changes in cytosolic free calcium and glucose uptake in adipocytes in obesity and non-insulin-dependent diabetes mellitus," Hormone Research, vol. 34, no. 1, pp. 39-44, 1990.

[19] Y. Ohno, H. Suzuki, H. Yamakawa, M. Nakamura, K. Otsuka, and T. Saruta, "Impaired insulin sensitivity in young, lean normotensive offspring of essential hypertensives: possible role of disturbed calcium metabolism," Journal of Hypertension, vol. 11, no. 4, pp. 421-426, 1993.

[20] M. B. Zemel, "Nutritional and endocrine modulation of intracellular calcium: implications in obesity, insulin resistance and hypertension," Molecular and Cellular Biochemistry, vol. 188, no. 1-2, pp. 129-136, 1998.

[21] B. Draznin, K. E. Sussman, R. H. Eckel, M. Kao, T. Yost, and N. A. Sherman, "Possible role of cytosolic free calcium concentrations in mediating insulin resistance of obesity and hyperinsulinemia," Journal of Clinical Investigation, vol. 82, no. 6, pp. 1848-1852, 1988.

[22] B. J. Boucher, N. Mannan, K. Noonan, C. N. Hales, and S. J. W. Evans, "Glucose intolerance and impairment of insulin secretion in relation to vitamin D deficiency in East London Asians," Diabetologia, vol. 38, no. 10, pp. 1239-1245, 1995.

[23] K. C. R. Baynes, B. J. Boucher, E. J. M. Feskens, and D. Kromhout, "Vitamin D, glucose tolerance anal insulinaemia in elderly men," Diabetologia, vol. 40, no. 3, pp. 344-347, 1997.

[24] K. C. Chiu, A. Chu, V. L. W. Go, and M. F. Saad, "Hypovitaminosis $\mathrm{D}$ is associated with insulin resistance and $\beta$ cell dysfunction," American Journal of Clinical Nutrition, vol. 79, no. 5, pp. 820-825, 2004.

[25] O. Gedik and S. Akalin, "Effects of vitamin D deficiency and repletion on insulin and glucagon secretion in man," Diabetologia, vol. 29, no. 3, pp. 142-145, 1986.

[26] A.-M. Borissova, T. Tankova, G. Kirilov, L. Dakovska, and R. Kovacheva, "The effect of vitamin D3 on insulin secretion and peripheral insulin sensitivity in type 2 diabetic patients," International Journal of Clinical Practice, vol. 57, no. 4, pp. 258261, 2003.

[27] L. Lind, T. Pollare, A. Hvarfner, H. Lithell, O. H. Sorensen, and S. Ljunghall, "Long-term treatment with active vitamin $\mathrm{D}$ (alphacalcidol) in middle-aged men with impaired glucose tolerance. Effects on insulin secretion and sensitivity, glucose tolerance and blood pressure," Diabetes Research, vol. 11, no. 3, pp. 141-147, 1989.

[28] E. Orwoll, M. Riddle, and M. Prince, "Effects of vitamin D on insulin and glucagon secretion in non-insulin- dependent diabetes mellitus," American Journal of Clinical Nutrition, vol. 59, no. 5, pp. 1083-1087, 1994.

[29] L. Lind, A. Hanni, H. Lithell, A. Hvarfner, O. H. Sorensen, and S. Ljunghall, "Vitamin D is related to blood pressure and other cardiovascular risk factors in middle-aged men," American Journal of Hypertension, vol. 8, no. 9, pp. 894-901, 1995.

[30] R. Scragg, M. Sowers, and C. Bell, "Serum 25-hydroxyvitamin $\mathrm{D}$, diabetes, and ethnicity in the Third National Health and Nutrition Examination Survey," Diabetes Care, vol. 27, no. 12, pp. 2813-2818, 2004. 


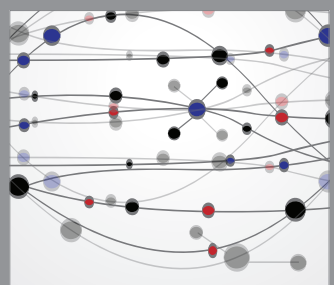

The Scientific World Journal
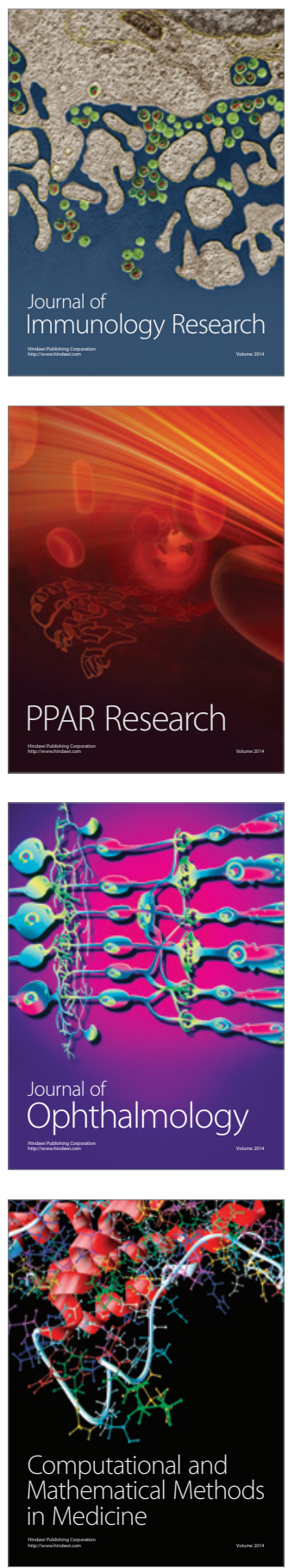

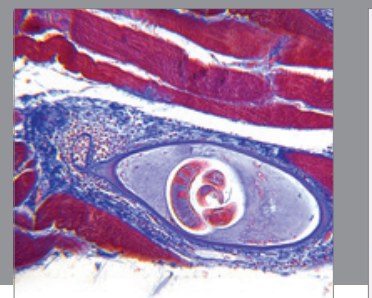

Gastroenterology

Research and Practice
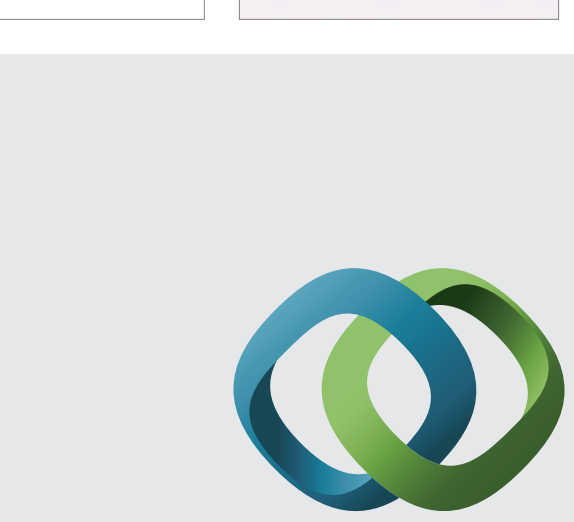

\section{Hindawi}

Submit your manuscripts at

http://www.hindawi.com
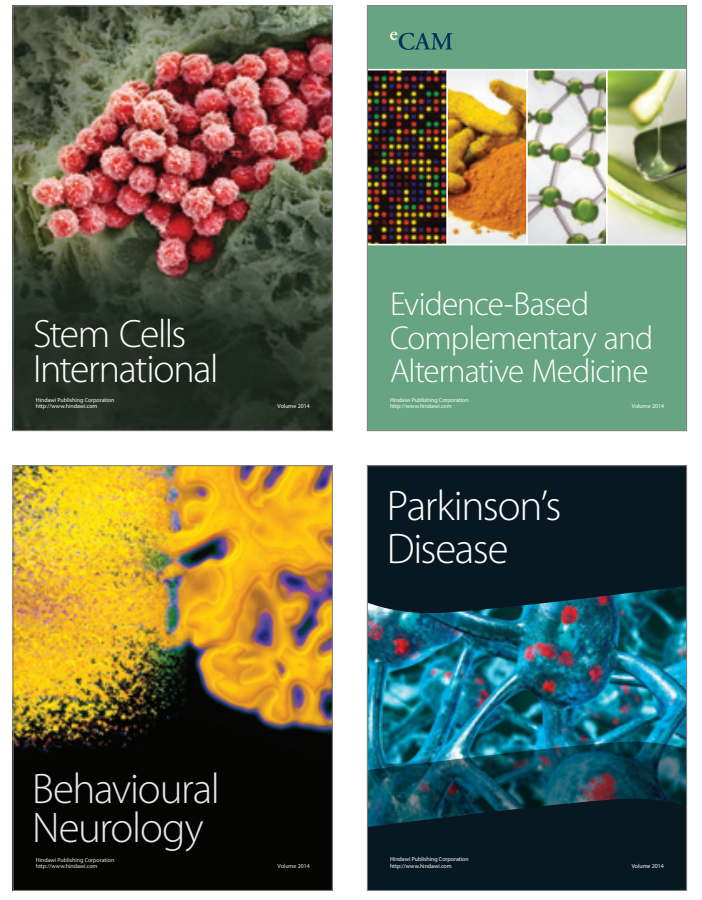
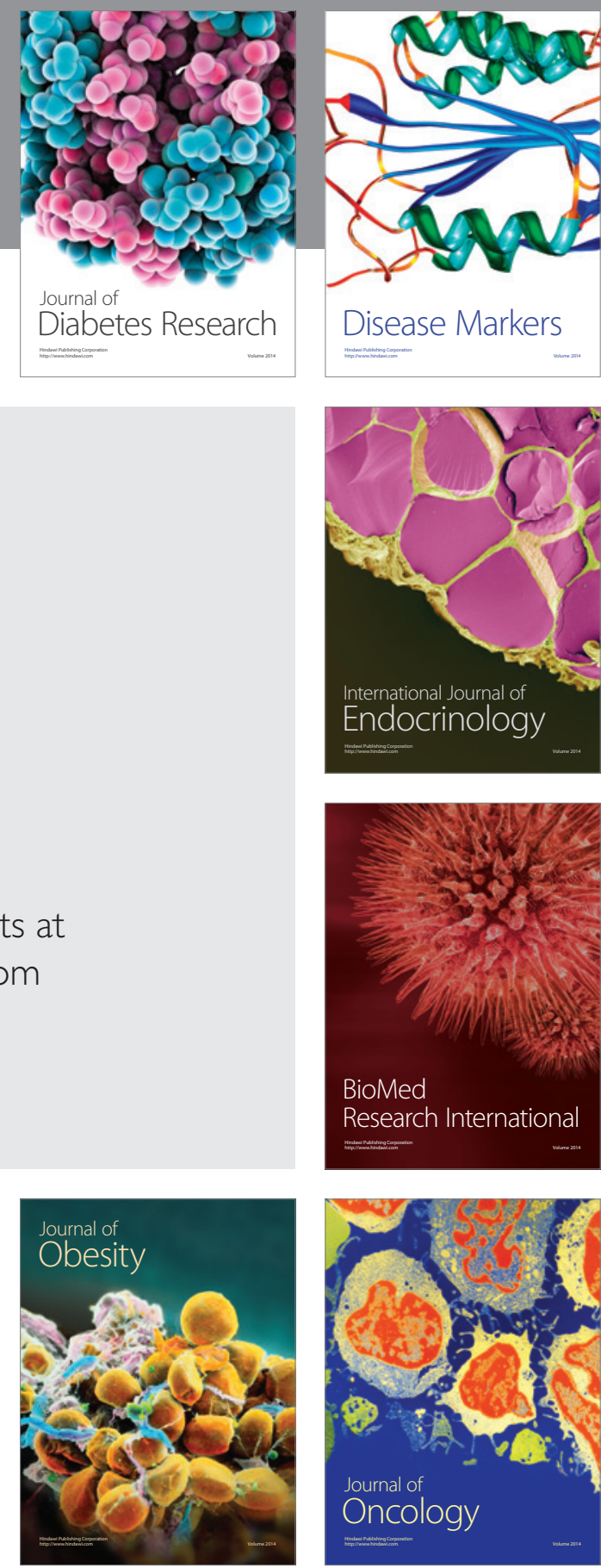

Disease Markers
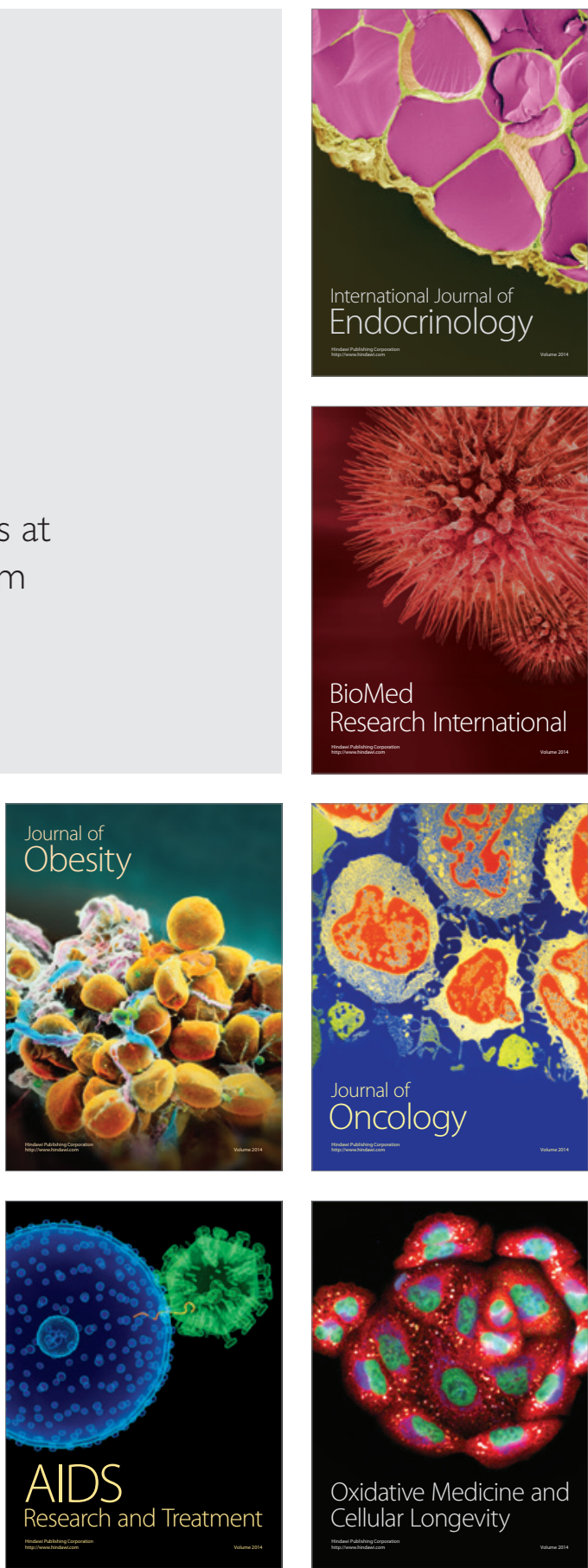